\title{
EDUCATION AS A KEY IN CAREER BUILDING
}

\author{
Miloš HITKA (D) ${ }^{1}$, Peter ŠTARCHOŇ (iD) ${ }^{2}$, Silvia LORINCOVÁ (D) ${ }^{*}$, Zdeněk CAHA (D) 4 \\ ${ }^{1,3}$ Department of Economics, Management and Business, Faculty of Wood Sciences and Technology, \\ Technical University in Zvolen, Zvolen, Slovak Republic \\ ${ }^{2}$ Department of Marketing, Faculty of Management, Comenius University in Bratislava, \\ Bratislava, Slovak Republic \\ ${ }^{4}$ Department of Human Resource Management, Faculty of Corporate Strategy, \\ Institute of Technology and Business in Ceske Budejovice, Ceske Budejovice, Czech Republic
}

Received 01 December 2020; accepted 19 May 2021

\begin{abstract}
Human resources in companies are gaining increasingly more strategic meaning by its ability to influence reaching company goals. The task of a manager is to understand the fact that every employee is different, has different needs, goals, and ambitions, is motivated by something else in every stage of career ladder. The aim of the paper is to define the influence of education in building the employee's career. The presumption if the level of education has influence on the career motivation factors is verified on the sample of 3,720 respondents. The results of the research have confirmed that the employee's career is influenced by the level of education significantly. Motivation factors education and personal growth, applying own skills, self-fulfillment, and autonomous decision-making are perceived differently in terms of importance and gender. Therefore, it is recommended the company managers to include into leading of employee's career also the level of education in the context of gender that influences employee's needs and interests.
\end{abstract}

Keywords: human resource management, career, education, gender, employees' motivation, contingency, Chi-square test, influence of education on career, influence of gender on career.

JEL Classification: I25, P36, O15.

\section{Introduction}

Career as a life path that an employee performs during individual's working life is mostly associated with the person of the individual. The importance of a career for a company is often underestimated. It is an area that is crucial for the business because human resources in companies are gaining increasingly more strategic meaning. A company that cares about its long-term presence on the market should be interested in supporting the personal and professional growth of its employees. Development activities should signal to employees that

\footnotetext{
*Corresponding author. E-mail: silvia.lorincova@tuzvo.sk
} 
the company is interested in employing them in the long run. The company investments will be returned by above-average performance of employees, the ability of employees to quickly adapt to changing conditions and requirements, building pride and loyalty to the company.

Each company should focus its development on those groups of employees who are important and represent its competitive advantage. According to the research of Weber and Rademacher (2020), Ashraf (2019), Guerrero et al. (2016), and Brown et al. (2010) the focus should be placed on leaders and talented employees with high potential for career. Career management is understood as a never-ending process of planning, recruitment, selection, development, management, and evaluation of talented employees (Hirschi et al., 2020). It is a competitive advantage and a strategic tool of the company in competition. If a company wants to be successful in the market, it must necessarily be different from the competition (Weng \& Zhu, 2020; Xie et al., 2020). Therefore, career management becomes a huge competitive advantage of the company (Litano \& Major, 2016).

Employee's career plays an important role in life. It is the way or procedure more precisely, that acts on timeline. It has the beginning in the period of starting the new job or school and ends in the current period. It is the professional career during which a human gains experience, skills and develops his potential. Every human walk on this professional path alone and has its personal potential in his hands. A man often searches for the meaning of his life in his employment. However, if he does not reach the professional self- fulfillment, he does not reach the life-fulfillment (Li \& Yeo, 2011).

Employee's career is not only known as a series of promotions and successful employment practices. It represents the coherence of work experiences in which the individual participates in work activities. It is a final path that allows to understand the behavior and actions of man in work and personal life. It should be the result of goals planned which are important in work and personal life. The aim of the career management at the level of individual development represents the work motivation of employees, who can estimate their perspective in the company and to focus on the development of personal potential. At the enterprise level, career management ensures the continuous development of its human capital and ensures the continuity of management processes by planning and securing successions in management positions (Son \& Kim, 2019; Gottwald et al., 2018).

In working life, there are number of factors that motivate employees to work. However, only some of them motivate the employee to career growth. If we want to understand the differences in the approach to career, the key is the research of the factors that motivate employees during their lives. The aim of the paper is to define the influence of education in career building of an employee in the area of working career. The object of the research are career motivation factors as work recognition, education, and personal growth, applying own skills, career advancement, self-fulfillment, autonomous decision-making, competencies, and prestige depending on education reached and gender.

The structure of the paper is as follows: firstly, the review of the literature associated with the issue is presented. Then, the aim of paper is defined and research methods such as contingency, Chi-square test are used. It is followed by the research findings and discussion. Finally, conclusions, limitation and future research direction are offered. 


\section{Theoretical developments}

Career has become the synonym for reaching personal or organizational goals. It is defined as a sequence in work or private life sphere. If it is perceived from the work point of view, it is either the procedure, abidance or decline in the sequence of work positions where it is dealt mainly with reaching and processing work experience and consequential creation of professional image. Career is symbolized by the image of an individual about his future. It is the continuous process happening during the whole process of individual's life by means of building relationships, involving himself in professional development, interviews, and constant setting of goals.

The procedure of career development means providing qualified and experienced people who are at disposal for organization (Gottwald et al., 2017). Their reliability that gains more and more strategic meaning because it influences reaching the goals of every organization is influenced by various factors (Kubal’a \& Vetráková, 2018). Recent research in the field (Stacho et al., 2019; Pancheva \& Antov, 2017; Kucharčíková et al., 2015) point out that one of them is education, that increases the productivity of an organization and it also flourishes every career move of individuals. The result of education and development is the expected positive contribution in accordance with what company expects (Krišták et al., 2014). Further research (Pancheva \& Antov, 2017; Mohyeldin \& Suliman, 2007) show that education and development of employees or professional preparation are commonly included in training which is the part of education process. According to the research of Nermec et al. (2017), further education of employees helps and supports fulfilment of main tasks because it provides declarative and procedural knowledge how to deal with the particular task and fulfill them. On one side, investments into education increase work productivity in organization and on the other side, they provide better socioeconomic status to individuals.

Education has become one of the basic presumption of employers who provide opportunities to people to work on their career. Many companies require certain level of education on the positions that did not require the education before. The lower level of education an employee currently has, the less chances he has to be employed and therefore education has become some barrier to many career inputs. Education is the key factor in opening career potential (Horak, 2017). Many people despite the fact that they work, they return to school and expand their knowledge (Kucharčíková \& Mičiak, 2018; Urbancová et al., 2016). There is hard work behind gaining degree, that returns not only in higher bonuses at work. By higher education, we do not raise only the career but also self-esteem, employer's recognition, and of course higher salary. All gained skills, abilities, and knowledge help in career path to any organization (Antov et al., 2017; Fejfarova \& Urbancova, 2015).

The important task of managers is to know the needs of their employees which motivate the work during the whole working life. Motivation represents the level of employee's ambition to perform the work disregarding his personal happiness. Motivation in management represents the way with which, a manager supports productivity and effectiveness of employees (Palm et al., 2020; Lejsková et al., 2017; Crandall, 2016). Many managers are persuaded that motivation comes out of their personal character; however, a good motivation 
consists mainly of the right dealing with employees, rewarding and creation of conditions for work (Renninger \& Hidi, 2015). Current research (Paais \& Pattiruhu, 2020; Morkevičiūte \& Endriulaitiené, 2020; Jad'ud'ová et al., 2018a) confirm that employees who are motivated enough are more productive, active and make enough effort and investment into work, create higher work value what leads them to higher education level. Therefore, it can be said that motivation is the factor to success in business with higher productivity.

Salary is often considered as the main factor that motivates employees (Ližbetinová, 2017; Zameer et al., 2014). However, employees can be motivated also by non-financial way more precisely by promotion or praise. The effort to create a good climate at workplace or the creation of a health and save work environment are also important (Gejdos et al., 2019; Naile \& Selesho, 2014; Muogbo, 2013). At the same time, it is necessary to take into consideration the fact that every employee is different, has different needs and he is motivated by something else in every stage of his career advancement. Therefore, it is necessary to choose the appropriate system of motivation because employees do not have to be motivated only by a specific factor but also by combination of various incentives. Moresová et al. (2019), Paluš et al. (2019), Potkány et al. (2019), Sedliačiková et al. (2019), Jad’udová et al. (2018b), and Štefancová et al. (2017) research confirms the fact that current trends, changing political, technological, and economic environment, digital revolution, growing globalisation and growing competition create a pressure on companies to keep their company processes of more quality. Therefore, companies are forced to retain its employees for example also by means of effective motivation, because otherwise there is a threat of leaving to competitive companies with better conditions (Ližbetinová, 2014).

\section{Methodology}

The research of career growth of employees depending on education was made by a method of questionnaire on the sample of 3,720 Slovak employees working in small and mediumsized enterprises. Composition of research sample is presented in Table 1.

Table 1. Composition of research sample

\begin{tabular}{|l|l|c|c|c|c|c|}
\hline Gender & \multicolumn{1}{|c|}{ Frequency / Education } & $\{1\}$ & $\{2\}$ & $\{3\}$ & $\{4\}$ & Total \\
\hline \multirow{3}{*}{ Male } & Frequency & 44 & 352 & 1,022 & 451 & 1,869 \\
\cline { 2 - 7 } & Line frequency (\%) & 2.35 & 18.83 & 54.68 & 24.13 & 100 \\
\cline { 2 - 7 } & Total frequency (\%) & 1.18 & 9.46 & 27.47 & 12.12 & 50.24 \\
\hline \multirow{3}{*}{ Female } & Frequency & 10 & 147 & 943 & 751 & 1,851 \\
\cline { 2 - 7 } & Line frequency (\%) & 0.54 & 7.94 & 50.95 & 40.57 & 100 \\
\cline { 2 - 7 } & Total frequency (\%) & 0.27 & 3.95 & 25.35 & 20.19 & 49.76 \\
\hline \multirow{2}{*}{ Total } & Frequency & 54 & 499 & 1,965 & 1,202 & 3,720 \\
\cline { 2 - 7 } & Total frequency (\%) & 1.45 & 13.41 & 52.82 & 32.31 & 100 \\
\hline
\end{tabular}

Note: $\{1\}=$ Primary education; $\{2\}=$ High school education without General Certificate of Secondary Exam (GCSE); $\{3\}=$ High school education with GCSE; $\{4\}=$ University education. 
The questionnaire was divided into two parts. In the first part socio-demographic features were studied. The features such as gender (male; female) and education (primary education; high school education without General Certificate of Secondary Exam (GCSE); high school education with GCSE; university education) were studied to find out their influence on the career motivation factors. The second part of questionnaire consisted of specific career motivation factors (applying own skills, autonomous decision-making, career advancement, competencies, education, and career growth, prestige, self-fulfillment, and work recognition). Respondents matched the weight of importance according to Likerty scale: 5 - very important, 4 - important, 3 - neutral, 2 - low importance, 1 - unimportant.

Statistic software STATISTICA 12 was used to reach the results. Firstly, motivation factors were tested using Cronbach's Alpha. The internal reliability of individual scales of all analyzed career motivation factors measured by the Cronbach's alpha reaches $\alpha=0.846$. Further, the correlation between the selected motivation factor (corrected item) and the rest of motivation factors (total correlation) was tested. The results were in all cases greater than 0.3 (values range from 0.531 to 0.642 ), which is according to de Vaus (2002) an indication that the items belong into the index and the index is one-dimensional. In addition, it is possible to see from Cronbach's Alpha column if item deleted that if a motivation factor is removed from the index, the alpha value would not increase. The results of Cronbach's Alpha testing for individual motivation factors are presented in Table 2.

Table 2. The results of Cronbach's Alpha testing

\begin{tabular}{|l|c|c|c|c|c|}
\hline \multicolumn{1}{|c|}{$\begin{array}{c}\text { Career motivation } \\
\text { factors }\end{array}$} & $\begin{array}{c}\text { Scale mean if } \\
\text { item deleted } \\
\text { item deleted }\end{array}$ & $\begin{array}{c}\text { Scale } \\
\text { variance if } \\
\text { item-total } \\
\text { correlation }\end{array}$ & $\begin{array}{c}\text { Corrected } \\
\text { multiple } \\
\text { correlation }\end{array}$ & $\begin{array}{c}\text { Cronbach's } \\
\text { Alpha if item } \\
\text { deleted }\end{array}$ \\
\hline Applying own skills & 28.127 & 19.980 & 0.558 & 0.329 & 0.831 \\
\hline Career advancement & 28.147 & 20.036 & 0.542 & 0.320 & 0.833 \\
\hline Competencies & 28.256 & 19.342 & 0.623 & 0.424 & 0.823 \\
\hline Prestige & 28.365 & 19.540 & 0.540 & 0.311 & 0.834 \\
\hline $\begin{array}{l}\text { Autonomous decision- } \\
\text { making }\end{array}$ & 28.158 & 19.555 & 0.628 & 0.441 & 0.823 \\
\hline Self-fulfillment & 28.154 & 19.313 & 0.642 & 0.458 & 0.821 \\
\hline $\begin{array}{l}\text { Education, and career } \\
\text { growth }\end{array}$ & 28.120 & 19.596 & 0.593 & 0.360 & 0.827 \\
\hline Work recognition & 28.002 & 20.194 & 0.531 & 0.290 & 0.834 \\
\hline
\end{tabular}

Subsequently, based on the p-value, statistical significance of career motivation factors was confirmed or rejected. The following hypotheses were tested by inductive statistics:

- $\mathrm{WH}_{0}$ - it is assumed that education level reached influence career motivation factors and they are dependent on them.

- $\mathrm{WH}_{1}$ - it is assumed that education level reached do not influence career motivation factors and are not dependent on them.

Chi-square test was used to determine the dependence or independence between the variable. The aim was to find out how the observed value of a given phenomena is signifi- 
cantly different from the expected value. Based on the p-value, the real level of importance was found out. If p-value is lower, the conviction is higher, $\mathrm{H}_{0}$ is rejected and statistical importance among features is confirmed. The level of importance was set on the basis of p-value $=0.05$ (Pacáková, 2009). Subsequently, the dependence between the two categorical features using contingency was tested. The contingency table contains data from the research of the dependence or independence of two qualitative traits A and B. The trait A represented gender and the respondents' education completed. The trait B represented individual career factors. The hypotheses were tested using Pearson's chi-square test.

\section{Results}

The level of career growth by means of career motivation factors (applying own skills, autonomous decision-making, competencies, education and personal growth, prestige, career advancement, self-fulfillment, work recognition) was defined firstly from the general point of view. Means of arithmetical average, standard deviation and confidence intervals were used to identify the most important career motivation factors for all respondents regardless of the education level reached and gender. The results are presented in Table 3.

Table 3. The importance of career motivation factors

\begin{tabular}{|c|l|c|c|c|r|}
\hline \multirow{2}{*}{ No. } & Career motivation factors & \multirow{2}{*}{ Average } & \multirow{2}{*}{$\begin{array}{c}\text { Standard } \\
\text { deviation }\end{array}$} & \multicolumn{2}{|c|}{ Confidence interval } \\
\cline { 5 - 5 } & & & $-95 \%$ & $95 \%$ \\
\hline 1. & Work recognition & 4.19 & 0.880 & 4.160 & 4.216 \\
\hline 2. & Education and personal growth & 4.07 & 0.905 & 4.040 & 4.098 \\
\hline 3. & Applying own skills & 4.06 & 0.884 & 4.035 & 4.092 \\
\hline 4. & Career advancement & 4.04 & 0.894 & 4.014 & 4.072 \\
\hline 5. & Self-fulfillment & 4.04 & 0.896 & 4.007 & 4.065 \\
\hline 6. & Autonomous decision-making & 4.03 & 0.874 & 4.004 & 4.060 \\
\hline 7. & Competencies & 3.93 & 0.911 & 3.904 & 3.963 \\
\hline 8. & Prestige & 3.83 & 0.979 & 3.794 & 3.856 \\
\hline
\end{tabular}

Table 3 shows that motivation factor work recognition motivated most to career growth among eight factors analyzed. Following the results, it can be stated that with a $95 \%$ confidence, when rating the work recognition, employees would give this factor an average rating from 4.160 to 4.216 in a similar research. The second most important factor was education and personal growth with average rating from 4.040 to 4.098 . Career motivation factor, possibility of applying own skills, was placed on the third place in importance. Employees would give this factor an average rating from 4.035 to 4.092 in a similar research.

Subsequently, the level of career growth by means of career motivation factors was analyzed from the point of view of education level reached. The opinions of respondents with primary education, high school education without GCSE, high school education with GCSE, and university education were analyzed via residual frequencies. 
Table 4. Influence of primary education on career growth

\begin{tabular}{|l|c|c|c|c|c|}
\hline \multicolumn{1}{|c|}{$\begin{array}{c}\text { Career motivation } \\
\text { factors }\end{array}$} & Unimportant & $\begin{array}{c}\text { Low } \\
\text { importance }\end{array}$ & Neutral & Important & $\begin{array}{c}\text { Very } \\
\text { important }\end{array}$ \\
\hline Work recognition & 3.58 & 2.09 & 13.06 & -15.10 & -3.63 \\
\hline $\begin{array}{l}\text { Education and personal } \\
\text { growth }\end{array}$ & 4.21 & 5.24 & 11.82 & -14.04 & -7.23 \\
\hline Applying own skills & 3.24 & 4.04 & 9.01 & -10.42 & -5.87 \\
\hline Career advancement & 0.58 & 9.95 & 9.36 & -19.37 & -0.52 \\
\hline Self-fulfillment & 3.36 & 9.47 & 3.74 & -17.80 & 1.23 \\
\hline $\begin{array}{l}\text { Autonomous decision- } \\
\text { making }\end{array}$ & 1.41 & 4.32 & 8.28 & -25.23 & 11.22 \\
\hline Competencies & 4.68 & 0.02 & 2.88 & -15.65 & 8.07 \\
\hline Prestige & 1.85 & 1.58 & -4.51 & -3.98 & 5.05 \\
\hline
\end{tabular}

Based on the results achieved in the area of influence of primary education on career growth presented in Table 4, it can be stated that career motivation factors autonomous decision-making, competencies and prestige were the most important motivation factors for respondents with primary education. Motivation factors work recognition, education and personal growth and applying own skills were rated neutrally. Respondents with primary education attributted the lowest importance to the motivation factors career advancement and self-fulfillment.

The results of testing career motivation factors in terms of high school education without GCSE are presented in Table 5.

Table 5. Influence of high school education without GCSE on career growth

\begin{tabular}{|l|c|c|c|c|c|}
\hline \multicolumn{1}{|c|}{ Career motivation factors } & $\begin{array}{c}\text { Unim- } \\
\text { portant }\end{array}$ & $\begin{array}{c}\text { Low } \\
\text { importance }\end{array}$ & Neutral & Important & $\begin{array}{c}\text { Very } \\
\text { important }\end{array}$ \\
\hline Work recognition & 4.28 & 24.16 & 30.68 & -18.81 & -40.31 \\
\hline Education and personal growth & 12.74 & 30.30 & 46.16 & -34.55 & -54.65 \\
\hline Applying own skills & 8.93 & 24.94 & 29.33 & 12.66 & -75.86 \\
\hline Career advancement & 11.27 & 8.35 & 26.22 & 6.49 & -52.33 \\
\hline Self-fulfillment & 9.71 & 34.04 & 41.13 & -33.62 & -51.27 \\
\hline Autonomous decision-making & 15.12 & 27.94 & 12.99 & -3.27 & -52.78 \\
\hline Competencies & 12.04 & 27.93 & 13.66 & -24.82 & -28.80 \\
\hline Prestige & 7.39 & 9.36 & 25.16 & -12.32 & -29.59 \\
\hline
\end{tabular}

According to the results presented in Table 5, respondents with high school education without GCSE prefer to evaluate most motivation factors neutrally. The lowest importance was attributed to motivation factors autonomous decision-making and competencies. Respondents did not consider any of the motivation factors analyzed as "very important" or "important". 
Table 6. Influence of high school education with GCSE on career growth

\begin{tabular}{|l|c|c|c|c|c|}
\hline Career motivation factors & Unimportant & $\begin{array}{c}\text { Low } \\
\text { importance }\end{array}$ & Neutral & Important & $\begin{array}{c}\text { Very } \\
\text { important }\end{array}$ \\
\hline Work recognition & -2.17 & -7.98 & -10.55 & -2.48 & 23.18 \\
\hline $\begin{array}{l}\text { Education and personal } \\
\text { growth }\end{array}$ & -13.22 & -15.26 & 16.63 & 15.24 & -3.40 \\
\hline Applying own skills & -1.68 & -19.06 & 9.45 & 11.02 & 0.27 \\
\hline Career advancement & -5.16 & -14.69 & -6.62 & -42.30 & 68.77 \\
\hline Self-fulfillment & -10.51 & -25.92 & 30.41 & 1.57 & 4.45 \\
\hline $\begin{array}{l}\text { Autonomous decision- } \\
\text { making }\end{array}$ & -11.43 & -28.67 & 49.07 & -22.10 & 13.13 \\
\hline Competencies & -5.54 & -2.62 & 8.54 & -21.15 & 20.77 \\
\hline Prestige & -4.31 & -6.38 & -14.45 & -2.11 & 27.25 \\
\hline
\end{tabular}

Respondents with high school education with GCSE consider career advancement, prestige, work recognition, and competencies as "very important" career motivation factors (Table 6). Motivation factor applying own skills was rated as "important". Autonomous decision-making, self-fulfillment, education, and personal growth were rated as "neutral".

Table 7. Influence of university education on career growth

\begin{tabular}{|l|c|c|c|c|c|}
\hline \multicolumn{1}{|c|}{$\begin{array}{c}\text { Career motivation } \\
\text { factors }\end{array}$} & Unimportant & $\begin{array}{c}\text { Low } \\
\text { importance }\end{array}$ & Neutral & Important & $\begin{array}{c}\text { Very } \\
\text { important }\end{array}$ \\
\hline Work recognition & -5.69 & -18.27 & -33.19 & 36.39 & 20.76 \\
\hline $\begin{array}{l}\text { Education and personal } \\
\text { growth }\end{array}$ & -3.73 & -20.28 & -74.61 & 33.35 & 65.27 \\
\hline Applying own skills & -10.50 & -9.91 & -47.79 & -13.26 & 81.46 \\
\hline Career advancement & -6.69 & -3.62 & -28.95 & 55.17 & -15.91 \\
\hline Self-fulfillment & -2.56 & -17.59 & -75.28 & 49.85 & 45.58 \\
\hline $\begin{array}{l}\text { Autonomous decision- } \\
\text { making }\end{array}$ & -5.10 & -3.59 & -70.34 & 50.59 & 28.44 \\
\hline Competencies & -11.17 & -25.33 & -25.08 & 61.62 & -0.04 \\
\hline Prestige & -4.93 & -4.56 & -6.21 & 18.41 & -2.71 \\
\hline
\end{tabular}

Table 7 shows that respondents with university education prefer to evaluate all career motivation factors analyzed as "very important" to "important".

In the next step, the level of career growth by means of career motivation factors was analyzed in more detailed way from the point of view of education level reached (primary education, high school education without GCSE, high school education with GCSE, university education) and gender (male, female). The results reached are presented in Table 8. 
Table 8. The importance of career motivation factors from the point of view of education level reached and gender

\begin{tabular}{|c|c|c|c|c|c|c|c|c|c|c|c|}
\hline \multirow{3}{*}{\multicolumn{2}{|c|}{\begin{tabular}{|c|} 
Indicator \\
Education / Gender \\
\end{tabular}}} & \multirow{2}{*}{\multicolumn{2}{|c|}{ Frequency }} & \multirow{2}{*}{\multicolumn{2}{|c|}{ Average }} & \multirow{2}{*}{\multicolumn{2}{|c|}{$\begin{array}{l}\text { Standard } \\
\text { deviation }\end{array}$}} & \multicolumn{4}{|c|}{ Confidence interval } \\
\hline & & & & & & & & \multicolumn{2}{|c|}{$-95 \%$} & \multicolumn{2}{|c|}{$95 \%$} \\
\hline & & $\{\mathrm{M}\}$ & $\{\mathrm{F}\}$ & $\{\mathrm{M}\}$ & $\{\mathrm{F}\}$ & $\{\mathrm{M}\}$ & $\{\mathrm{F}\}$ & $\{\mathrm{M}\}$ & $\{\mathrm{F}\}$ & $\{\mathrm{M}\}$ & $\{\mathrm{F}\}$ \\
\hline \multirow{4}{*}{$\begin{array}{l}\text { Work } \\
\text { recognition }\end{array}$} & $\{1\}$ & 44 & 10 & 4.21 & 3.60 & 1.002 & 1.265 & 3.900 & 2.695 & 4.509 & 4.505 \\
\hline & $\{2\}$ & 352 & 147 & 4.08 & 4.20 & 0.971 & 0.889 & 3.975 & 4.052 & 4.178 & 4.342 \\
\hline & $\{3\}$ & 1,022 & 943 & 4.14 & 4.18 & 0.934 & 0.879 & 4.087 & 4.126 & 4.201 & 4.239 \\
\hline & $\{4\}$ & 451 & 751 & 4.27 & 4.26 & 0.792 & 0.781 & 4.195 & 4.208 & 4.342 & 4.320 \\
\hline \multirow{4}{*}{$\begin{array}{l}\text { Education } \\
\text { and personal } \\
\text { growth }\end{array}$} & $\{1\}$ & 44 & 10 & 3.98 & 3.60 & 1.089 & 1.350 & 3.646 & 2.634 & 4.308 & 4.566 \\
\hline & $\{2\}$ & 352 & 147 & 3.83 & 3.95 & 1.054 & 0.942 & 3.728 & 3.792 & 3.949 & 4.099 \\
\hline & $\{3\}$ & 1,022 & 943 & 4.06 & 4.07 & 0.922 & 0.915 & 4.001 & 4.013 & 4.114 & 4.130 \\
\hline & $\{4\}$ & 451 & 751 & 4.23 & 4.13 & 0.825 & 0.784 & 4.154 & 4.074 & 4.307 & 4.187 \\
\hline \multirow{4}{*}{$\begin{array}{l}\text { Applying own } \\
\text { skills }\end{array}$} & $\{1\}$ & 44 & 10 & 4.14 & 3.30 & 0.979 & 0.675 & 3.839 & 2.817 & 4.434 & 3.783 \\
\hline & $\{2\}$ & 352 & 147 & 3.84 & 4.01 & 0.996 & 0.876 & 3.739 & 3.871 & 3.948 & 4.156 \\
\hline & $\{3\}$ & 1,022 & 943 & 4.04 & 4.04 & 0.899 & 0.874 & 3.986 & 3.986 & 4.096 & 4.097 \\
\hline & $\{4\}$ & 451 & 751 & 4.20 & 4.16 & 0.817 & 0.832 & 4.124 & 4.098 & 4.275 & 4.217 \\
\hline \multirow{4}{*}{$\begin{array}{l}\text { Career } \\
\text { advancement }\end{array}$} & $\{1\}$ & 44 & 10 & 4.09 & 3.70 & 1.007 & 1.160 & 3.785 & 2.871 & 4.397 & 4.529 \\
\hline & $\{2\}$ & 352 & 147 & 3.98 & 4.05 & 0.923 & 0.878 & 3.883 & 3.904 & 4.077 & 4.191 \\
\hline & $\{3\}$ & 1,022 & 943 & 4.08 & 4.03 & 0.907 & 0.899 & 4.025 & 3.970 & 4.136 & 4.085 \\
\hline & $\{4\}$ & 451 & 751 & 4.08 & 4.02 & 0.858 & 0.871 & 3.996 & 3.960 & 4.155 & 4.085 \\
\hline \multirow{4}{*}{ Self-fulfillment } & $\{1\}$ & 44 & 10 & 4.00 & 3.40 & 1.078 & 0.966 & 3.672 & 2.709 & 4.328 & 4.091 \\
\hline & $\{2\}$ & 352 & 147 & 3.87 & 4.00 & 0.988 & 0.844 & 3.763 & 3.862 & 3.970 & 4.138 \\
\hline & $\{3\}$ & 1,022 & 943 & 3.99 & 4.02 & 0.928 & 0.900 & 3.934 & 3.967 & 4.048 & 4.082 \\
\hline & $\{4\}$ & 451 & 751 & 4.20 & 4.11 & 0.798 & 0.832 & 4.121 & 4.052 & 4.269 & 4.171 \\
\hline \multirow{4}{*}{$\begin{array}{l}\text { Autonomous } \\
\text { decision- } \\
\text { making }\end{array}$} & $\{1\}$ & 44 & 10 & 4.23 & 3.40 & 0.985 & 0.966 & 3.928 & 2.709 & 4.527 & 4.091 \\
\hline & $\{2\}$ & 352 & 147 & 3.85 & 4.03 & 0.959 & 0.887 & 3.749 & 3.889 & 3.950 & 4.179 \\
\hline & $\{3\}$ & 1,022 & 943 & 3.99 & 4.02 & 0.896 & 0.880 & 3.939 & 3.965 & 4.049 & 4.077 \\
\hline & $\{4\}$ & 451 & 751 & 4.17 & 4.10 & 0.821 & 0.791 & 4.093 & 4.042 & 4.244 & 4.155 \\
\hline \multirow{4}{*}{ Competencies } & $\{1\}$ & 44 & 10 & 4.07 & 3.80 & 1.065 & 1.033 & 3.744 & 3.061 & 4.392 & 4.539 \\
\hline & $\{2\}$ & 352 & 147 & 3.83 & 3.93 & 1.026 & 0.948 & 3.730 & 3.777 & 3.946 & 4.087 \\
\hline & $\{3\}$ & 1,022 & 943 & 3.96 & 3.87 & 0.907 & 0.928 & 3.907 & 3.808 & 4.019 & 3.927 \\
\hline & $\{4\}$ & 451 & 751 & 4.00 & 3.98 & 0.851 & 0.849 & 3.917 & 3.917 & 4.074 & 4.038 \\
\hline \multirow{4}{*}{ Prestige } & $\{1\}$ & 44 & 10 & 3.91 & 3.80 & 0.960 & 1.317 & 3.617 & 2.858 & 4.201 & 4.742 \\
\hline & $\{2\}$ & 352 & 147 & 3.82 & 3.89 & 1.046 & 1.054 & 3.708 & 3.719 & 3.928 & 4.063 \\
\hline & $\{3\}$ & 1,022 & 943 & 3.87 & 3.75 & 0.974 & 0.993 & 3.810 & 3.686 & 3.930 & 3.813 \\
\hline & $\{4\}$ & 451 & 751 & 3.91 & 3.79 & 0.943 & 0.935 & 3.824 & 3.725 & 3.999 & 3.859 \\
\hline
\end{tabular}

Note: $\{1\}=$ Primary education; $\{2\}=$ High school education without GCSE; $\{3\}=$ High school education with GCSE; $\{4\}=$ University education; $\{\mathrm{M}\}=$ Male; $\{\mathrm{F}\}=$ Female. 
According to the results presented in Table 8 it can be further observed that from the point of view of gender, men with primary education are motivated most to their career growth by motivation factors autonomous decision-making, work recognition and applying their own skills. Men with high school education without GCSE are motivated most to their career growth by motivation factors work recognition, career advancement and self-fulfillment. Work recognition, career advancement, education and personal growth were three most important motivation factors for men with high school education with GCSE. Men with university education are motivated to their career growth mainly by work recognition, education, and personal growth, applying their own skills.

Women with primary education considered prestige, competencies, and work recognition as the most important career motivation factors. Work recognition, career advancement, autonomous decision making were the most important factors for women with high school education without GCSE. Women with high school education with GCSE evaluated work recognition, education and personal growth and applying own skills as the most important factors motivating them to their career growth most. For women with university education, work recognition, applying their own skills, education and personal growth were the most important factors.

In the next step, the influence of education level reached and gender on the career growth by means of career motivation factors (work recognition, education and personal growth, applying own skills, career advancement, self-fulfillment, autonomous decision-making, competencies, prestige) was tested using statistical methods. Following tables (Tables 9-12) present the results of the statistic testing. Statistically significant differences were confirmed at the significance level of $5 \%$.

Education, and personal growth was the first career motivation factor where the influence of education level reached and gender on the career growth was confirmed. Results are presented in Table 9.

Table 9. Results of statistic testing of the influence of education level reached and gender on career motivation factor education and personal growth

\begin{tabular}{|c|c|c|c|c|c|c|c|c|c|}
\hline \multirow{4}{*}{ Gender } & Gender & \multicolumn{4}{|c|}{ Male } & \multicolumn{4}{c|}{ Female } \\
\cline { 2 - 11 } & Average & 3.98 & 3.38 & 4.06 & 4.23 & 3.60 & 3.95 & 4.07 & 4.13 \\
\cline { 2 - 11 } & Education & $\{1\}$ & $\{2\}$ & $\{3\}$ & $\{4\}$ & $\{1\}$ & $\{2\}$ & $\{3\}$ & $\{4\}$ \\
\hline \multirow{4}{*}{ Male } & $\{1\}$ & & 0.996 & 1.000 & 0.892 & 0.982 & 1.000 & 1.000 & 0.993 \\
\cline { 2 - 11 } & $\{2\}$ & 0.996 & & $0.027^{*}$ & $0.000^{*}$ & 0.999 & 0.971 & $0.014^{*}$ & $0.000^{*}$ \\
\cline { 2 - 11 } & $\{3\}$ & 1.000 & $0.027^{*}$ & & 0.076 & 0.949 & 0.963 & 1.000 & 0.771 \\
\cline { 2 - 11 } & $\{4\}$ & 0.892 & $0.000^{*}$ & 0.076 & & 0.771 & 0.118 & 0.135 & 0.707 \\
\hline \multirow{4}{*}{ Female } & $\{1\}$ & 0.982 & 0.999 & 0.949 & 0.771 & & 0.990 & 0.941 & 0.893 \\
\cline { 2 - 11 } & $\{2\}$ & 1.000 & 0.971 & 0.963 & 0.118 & 0.990 & & 0.934 & 0.647 \\
\cline { 2 - 10 } & $\{3\}$ & 1.000 & $0.014^{*}$ & 1.000 & 0.135 & 0.941 & 0.934 & & 0.907 \\
\cline { 2 - 10 } & $\{4\}$ & 0.993 & $0.000^{*}$ & 0.771 & 0.707 & 0.893 & 0.647 & 0.907 & \\
\hline
\end{tabular}

Note: $\{1\}=$ Primary education; $\{2\}=$ High school education without GCSE; $\{3\}=$ High school education with GCSE; $\{4\}=$ University education; Approximate probability for the post hoc tests Error: intergroup. No $=0.811$. Degree of freedom $=3,712.0 ;{ }^{*} \mathrm{p}<.05$. 
Based on the result presented in Table 9 it can be stated that the most statistically significant differences were confirmed when analyzing motivation factors education and personal growth. The motivation factor education and personal growth is perceived differently by men with high school education with and without GCSE. Men with university education perceived motivation factor education and personal growth differently as men with high school education without GCSE. Differences were confirmed when comparing women with high school education with GCSE and men with high school education without GCSE. The last difference was confirmed between women with university education and men with high school education without GCSE.

According to the results presented in Table 10 it can be observed that the existence of differences in perceiving career motivation factor applying own skills was confirmed between men with university education and men with high school education without GCSE. Further differences were confirmed among women with university education and men with high school education without GCSE.

Table 10. Results of statistic testing of the influence of education level reached and gender on career motivation factor applying own skills

\begin{tabular}{|l|c|c|c|c|c|c|c|c|c|}
\hline \multirow{4}{*}{ Gender } & Gender & \multicolumn{4}{|c|}{ Male } & \multicolumn{4}{c|}{ Female } \\
\cline { 2 - 10 } & Average & 3.84 & 3.94 & 3.81 & 3.91 & 3.86 & 3.81 & 3.76 & 3.87 \\
\cline { 2 - 11 } & Education & $\{1\}$ & $\{2\}$ & $\{3\}$ & $\{4\}$ & $\{1\}$ & $\{2\}$ & $\{3\}$ & $\{4\}$ \\
\hline \multirow{4}{*}{ Male } & $\{1\}$ & & 0.774 & 1.000 & 1.000 & 0.397 & 0.998 & 1.000 & 1.000 \\
\cline { 2 - 11 } & $\{2\}$ & 0.774 & & 0.058 & $0.000^{*}$ & 0.865 & 0.716 & 0.058 & $0.000^{*}$ \\
\cline { 2 - 10 } & $\{3\}$ & 1.000 & 0.058 & & 0.120 & 0.561 & 1.000 & 1.000 & 0.172 \\
\cline { 2 - 10 } & $\{4\}$ & 1.000 & $0.000^{*}$ & 0.120 & & 0.300 & 0.611 & 0.122 & 0.996 \\
\hline \multirow{4}{*}{ Female } & $\{1\}$ & 0.397 & 0.865 & 0.561 & 0.300 & & 0.610 & 0.561 & 0.364 \\
\cline { 2 - 10 } & $\{2\}$ & 0.998 & 0.716 & 1.000 & 0.611 & 0.610 & & 1.000 & 0.858 \\
\cline { 2 - 10 } & $\{3\}$ & 1.000 & 0.058 & 1.000 & 0.122 & 0.561 & 1.000 & & 0.174 \\
\cline { 2 - 10 } & $\{4\}$ & 1.000 & $0.000^{*}$ & 0.172 & 0.996 & 0.364 & 0.858 & 0.174 & \\
\hline
\end{tabular}

Note: $\{1\}=$ Primary education; $\{2\}=$ High school education without GCSE; $\{3\}=$ High school education with GCSE; $\{4\}=$ University education; Approximate probability for the post hoc tests Error: intergroup. No $=0.773$. Degree of freedom $=3,712.0 ;{ }^{*} p<.05$.

More differences were confirmed when analyzing motivation factor self-fulfillment. The results are presented in Table 11.

Statistically significant differences were confirmed between men with university education and men with high school education with and without GCSE (Table 11). Self-fulfillment is perceived by women with university education differently than men with high school education without GCSE. 
Table 11. Results of statistic testing of the influence of education level reached and gender on career motivation factor self-fulfillment

\begin{tabular}{|c|c|c|c|c|c|c|c|c|c|}
\hline \multirow{4}{*}{ Gender } & Gender & \multicolumn{4}{|c|}{ Male } & \multicolumn{4}{c|}{ Female } \\
\cline { 2 - 10 } & Average & 4.00 & 3.87 & 3.99 & 4.20 & 3.40 & 4.00 & 4.02 & 4.11 \\
\cline { 2 - 11 } & Education & $\{1\}$ & $\{2\}$ & $\{3\}$ & $\{4\}$ & $\{1\}$ & $\{2\}$ & $\{3\}$ & $\{4\}$ \\
\hline \multirow{4}{*}{ Male } & $\{1\}$ & & 0.997 & 1.000 & 0.971 & 0.805 & 1.000 & 1.000 & 0.999 \\
\cline { 2 - 11 } & $\{2\}$ & 0.997 & & 0.582 & $0.000^{*}$ & 0.941 & 0.905 & 0.267 & $0.006^{*}$ \\
\cline { 2 - 11 } & $\{3\}$ & 1.000 & 0.582 & & $0.014^{*}$ & 0.817 & 1.000 & 0.993 & 0.148 \\
\cline { 2 - 11 } Female & $\{4\}$ & 0.971 & $0.000^{*}$ & $0.014^{*}$ & & 0.486 & 0.568 & 0.078 & 0.857 \\
\cline { 2 - 11 } & $\{1\}$ & 0.805 & 0.941 & 0.817 & 0.486 & & 0.805 & 0.771 & 0.630 \\
\cline { 2 - 11 } & $\{2\}$ & 1.000 & 0.905 & 1.000 & 0.568 & 0.805 & & 1.000 & 0.962 \\
\cline { 2 - 11 } & $\{3\}$ & 1.000 & 0.267 & 0.993 & 0.078 & 0.771 & 1.000 & & 0.551 \\
\hline
\end{tabular}

Note: $\{1\}=$ Primary education; $\{2\}=$ High school education without GCSE; $\{3\}=$ High school education with GCSE; $\{4\}=$ University education; Approximate probability for the post hoc tests Error: intergroup. No $=0.795$. Degree of freedom $=3,712.0 ;{ }^{*} p<.05$.

Table 12. Results of statistic testing of the influence of education level reached and gender on career motivation factor autonomous decision-making

\begin{tabular}{|c|c|c|c|c|c|c|c|c|c|}
\hline \multirow{4}{*}{ Gender } & Gender & \multicolumn{4}{|c|}{ Male } & \multicolumn{4}{c|}{ Female } \\
\cline { 2 - 11 } & Average & 4.23 & 3.85 & 3.99 & 4.17 & 3.40 & 4.03 & 4.02 & 4.10 \\
\cline { 2 - 11 } & Education & $\{1\}$ & $\{2\}$ & $\{3\}$ & $\{4\}$ & $\{1\}$ & $\{2\}$ & $\{3\}$ & $\{4\}$ \\
\hline \multirow{4}{*}{ Male } & $\{1\}$ & & 0.457 & 0.914 & 1.000 & 0.398 & 0.968 & 0.955 & 0.997 \\
\cline { 2 - 11 } & $\{2\}$ & 0.457 & & 0.348 & $0.000^{*}$ & 0.944 & 0.607 & 0.149 & $0.004^{*}$ \\
\cline { 2 - 11 } & $\{3\}$ & 0.914 & 0.348 & & 0.053 & 0.793 & 1.000 & 0.998 & 0.279 \\
\cline { 2 - 11 } Female & $\{4\}$ & 1.000 & $0.000^{*}$ & 0.053 & & 0.499 & 0.889 & 0.178 & 0.930 \\
\hline & $\{1\}$ & 0.398 & 0.944 & 0.793 & 0.499 & & 0.732 & 0.753 & 0.623 \\
\cline { 2 - 11 } & $\{2\}$ & 0.968 & 0.607 & 1.000 & 0.889 & 0.732 & & 1.000 & 0.998 \\
\cline { 2 - 10 } & $\{3\}$ & 0.955 & 0.149 & 0.998 & 0.178 & 0.753 & 1.000 & & 0.673 \\
\hline
\end{tabular}

Note: $\{1\}=$ Primary education; $\{2\}=$ High school education without GCSE; $\{3\}=$ High school education with GCSE; $\{4\}=$ University education; Approximate probability for the post hoc tests Error: intergroup. No $=0.757$. Degree of freedom $=3,712.0 ;{ }^{*} p<.05$.

The further differences were confirmed when analyzing the opinions of men with university education and men with high school education without GCSE in the perception of career motivation factor autonomous decision making (Table 12). Women with university education perceive the factor analyzed differently than men with high school education without GCSE.

Motivation factors work recognition, career advancement, competencies and prestige were evaluated by respondents in very similar way, regardless of the education level reached. 


\section{Discussion}

In the reaction to current trends, companies are forced to innovate their processes in order to retain their employees or there is the threat of employees leaving to competitor and potential survival of a company can be endangered (Nouri \& Mousavi, 2020; Pham et al., 2019; Kampf et al., 2018). Within this context it is necessary to motivate employees because researches that dealt with employee motivation (Azis et al., 2019; Čiarnienè et al., 2019; Mulyani et al., 2019) focus on the fact that motivated employees will look at the tasks better way, quality oriented and will work more effectively and with higher productivity. Effective motivation will consequently reflect in reaching good work results. The task of manager is to understand the fact that every employee, regardless of the age, gender, or education, has own goals and ambitions in his life, that he wants to achieve (Haeruddin et al., 2020; Joniaková \& Blštáková, 2015). Therefore, if we want to understand the differences in the approach to career growth, the key is to investigate the influence of education level reached in employee's career.

Following the results of the research where the influence of education in building the employee's career was defined in general point of view (regardless the gender), it can be concluded that employees with primary education are motivated most to their career growth by motivation factor autonomous decision-making. Similar outcomes were confirmed when analyzing the level of career growth from the point of view of gender. Men with primary education are motivated most to their career growth by motivation factor autonomous decisionmaking. Women with primary education put on the first place in the career growth, prestige. Gender differences observed between men and women were confirmed in the research of Salem and Yount (2019), Fernández-Muñoz and Topa (2018), Brady and King (2018), Donnelly (2015), Gress and Paek (2014), and Fotaki (2013). Based on the research results it can be concluded that women long for special status in company. It is important for them, to be noticed by others and they try all the time to progress in their work. Some Slovak women aspire for a special status. Some women compare themselves. At the same time, some women compare to men. Not all men aspire career growth and only selected individuals rise in career ladder. Furthermore, in Slovakia, in the area of careers, gender differences can be observed in term of age. In most cases, women begin to build their careers around the age of 40. It is influenced by the fact that women are involved in the family and raising children. Only when the children are independent, then women aspire for a career. Men build their careers from the age of 30 .

Respondents with high school education without GCSE have the tendency to evaluate career motivation factors neutrally. Based on the results it can be further concluded that the higher the education level reached, the career growth is more important. The statement is confirmed by the similar outcomes observed in employees with higher education than high school education without GCSE. More qualified employees have the tendency consider career motivation factors "important" to "very important". The results are confirmed by the research results of Sánchez-Sellero et al. (2018) according to which an employee motivated by motivation factors relating to career aspiration will tend to move up the corporate ladder.

Successful manager has to know the needs of his employees to be able to motivate them effectively. Subsequently effective motivation is reflected in reaching good working results 
(Smela et al., 2018; Elkin et al., 2017). Regarding this, the fact has to be taken into account, that every employee is different, has different needs and is motivated by something else (Omondi et al., 2019). A man can be motivated by everything what activates him to performance, determinates his direction and goal of performances, i. e. it can be needs, values, thoughts, and goals that man realizes (Kontodimopoulos et al., 2009). Employees need not be motivated by a specific factor but also by combination of various incentives. Many factors exist that are divided into work, social, financial, relation and career factors (Xanthakis, 2019; Murphy et al., 2010). Every employee prefers the importance of different factor that will drive him forward in reaching good results. Further direction of the research of career growth of employees can be seen in depending on age and seniority. Furthermore, it will be interesting to observe how the current pandemic affects career growth of employees.

Right motivation leads employees to a specific career advancement in professional life as well as in private life, what means a certain career. Every employee disregarding his gender, education, race or religion has goals, dreams and ambitions in his life, which he wants and tries to reach. If he has a work that he likes and is good at it then he wants to proceed higher and expand his scope of knowledge. The presumption that the level of education level reached has influence on the level of career growth by means of career motivation factors was confirmed.

\section{Conclusions}

The work potential of employees needs to be developed. With this development the company is gaining better quality and more valuable human resources. It is the success of the company that is significantly influenced by the employees. Therefore, every organization should provide to employees the space and opportunities for development. An important part of an individual career management is the company where the employee works. Some companies understand this issue as a complete transposition of employee decisions about the future of employees. As part of the career management process, it is in the interest of the company to ensure that each job position is filled with the most suitable candidates, to set clear targets for employees at all levels of management and to equire employees to provide appropriate work performance. In the process of career management, plan succession in managerial positions is important. Succession planning allows to have motivated and loyal employees available for key positions where competencies, skills, and knowledge of the business model are required. Talented employees are a long-term benefit for every company. Development activities should signal to employees that the company is interested in employing them in the long run. Employees who complete long-term programs and participate in decision-making are more loyal to the company. The company investments will be returned by above-average performance of employees. Therefore, more than ever before, the management of the company must form a clear idea of the individual and collective strengths of its employees. Management must be sure of the ability of employees to achieve better quality work performance. All methods of talent management are directed towards a single goal, and thus the efficient and long-term use of strategic human capital. 
More companies in Slovakia begin to apply the process of managing career to increase their competitiveness and improve the structure of workforce. The career planning and succession enables a company to plan better its own goals and activities. If a company applies the process of career management and promotes this fact in public, it becomes very lucrative for the potential new employees. New employees in this company look for the work also by themselves and therefore big amount of potential talents will come to this company. However, in this context it is necessary to put into career management also education level reached that influences needs and interests of employees.

\section{Acknowledgements}

The research was supported by KEGA 005TU Z-4/2020 Economics, Management and Enterprising in Wood Industry Companies - university textbook with visualization support in virtual space, VEGA 1/0737/20 Consumer literacy and intergenerational changes in consumer preferences when purchasing Slovak products, and VEGA 1/0161/21 Dependence of the type of corporate culture on the industries of Slovak enterprises and selected socio-demographic factors. This publication is the result of the project implementation: Progressive research of performance properties of wood-based materials and products (LignoPro), supported by the Operational Programme Integrated Infrastructure (OPII) funded by the ERDF.

\section{Author contributions}

$\mathrm{MH}, \mathrm{PS}$, SL, and ZC conceived the study and were responsible for the design and development of the data analysis. MH, PŠ, SL, and ZC were responsible for data collection and analysis. $\mathrm{MH}, \mathrm{PS}$, SL, and ZC were responsible for data interpretation. $\mathrm{MH}, \mathrm{PS}$, SL, and ZC wrote the first draft of the article.

\section{References}

Antov, P., Pancheva, T. V., \& Santas, P. (2017). Cooperative learning approach in engineering education. Science, Engineering \& Education, 2(1), 106-111.

Ashraf, M. A. (2019). The mediating role of work atmosphere in the relationship between supervisor cooperation, career growth and job satisfaction. Journal of Workplace Learning, 31(2), 78-94. https://doi.org/10.1108/JWL-12-2017-0113

Azis, E., Prasetio, A. P., Gustyana, T. T., Putri, S. F., \& Rakhmawati, D. (2019). The mediation of intrinsic motivation and affective commitment in the relationship of transformational leadership and employee engagement in technology-based companies. Polish Journal of Management Studies, 20(1), 54-63. https://doi.org/10.17512/pjms.2019.20.1.05

Brady, P. Q., \& King, W. R. (2018). Brass satisfaction: Identifying the personal and work-related factors associated with job satisfaction among police chiefs. Police Quarterly, 21, 250-277. https://doi.org/10.1177/1098611118759475

Brown, A. D., Kornberger, M., Clegg, S. R., \& Carter, C. (2010). Invisible walls and silent hierarchies: A case study of power relations in an architecture firm. Human Relations, 63(4), 525-549.

https://doi.org/10.1177/0018726709339862 
Crandall, M. (2016). Motivational management the sandler way. Sandler Training, London, UK.

Čiarnienè, R., Suprikienė, R., Čiutienè, R., Daunorienė, A., \& Riklikienè, O. (2019). Managing human resources in nursing. Journal of Business Economics and Management, 20(1), 192-207. https://doi.org/10.3846/jbem.2019.8339

De Vaus, D. (2002). Analyzing social science data: 50 key problems in data analysis. SAGE Publications.

Dobrodolac, M., Švadlenka, L., Čubranić-Dobrodolac, M., Čičević, S., \& Stanivuković, B. (2018). A model for the comparison of business units. Personnel Review, 47(1), 150-165. https://doi.org/10.1108/PR-02-2016-0022

Donnelly, R. (2015). Gender, careers and flexibility in consultancies in the UK and the USA: A multilevel relational analysis. The International Journal of Human Resource Management, 26(1), 80-99. https://doi.org/10.1080/09585192.2014.934889

Elkin, S. E., Elkina, O. S., \& Metelev, S. Y. (2017). Design methods of human development management system. International Journal for Quality Research, 11(3), 559-572. https://doi.org/10.18421/IJQR11.03-05

Fejfarova, M., \& Urbancova, H. (2015). Application of the competency-based approach in organisations in the Czech Republic. E \& M Ekonomie a Management, 18(1), 111-122. https://doi.org/10.15240/tul/001/2015-1-009

Fernández-Muñoz, J. J., \& Topa, G. (2018). Older workers and affective job satisfaction: Gender invariance in Spain. Frontiers in Psychology, 9, 930. https://doi.org/10.3389/fpsyg.2018.00930

Fotaki, M. (2013). No woman is like a man (In academia): The masculine symbolic order and the unwanted female body. Organization Studies, 34(9), 1251-1275. https://doi.org/10.1177/0170840613483658

Gejdos, M., Vlckova, M., Allmanova, Z., \& Balazova, Z. (2019). Trends in workplace injuries in Slovak forest enterprises. International Journal of Environmental Research and Public Health, 16(1), 141. https://doi.org/10.3390/ijerph16010141

Gottwald, D., Svadlenka, L., Lejskova, P., \& Pavlisova, H. (2017). Human capital as a tool for predicting development of transport and communications sector. Communications, 19(4), 50-56.

Gottwald, D., Zákorová, E., Švadlenka, L., \& Pavlisová, H. (2018). Approach to human capital in National Postal Providers: A cross-country analysis in Europe. Promet - Traffic - Traffico, 30(5), 623633. https://doi.org/10.7307/ptt.v30i5.2744

Gress, D. R., \& Paek, J. (2014). Differential spaces in Korean places? Feminist geography and female managers in South Korea. Gender Work and Organization, 21(2), 165-186. https://doi.org/10.1111/gwao.12028

Guerrero, S., Jeanblanc, H., \& Veilleux, M. (2016). Development idiosyncratic deals and career success. Career Development International, 21(1), 19-30. https://doi.org/10.1108/CDI-08-2015-0115

Haeruddin, M. I. M., Pick, D., \& Thein, H. H. (2020). Resistance and compliance in women's academic identity work in the Global South. Higher Education Quarterly, 74(3), 257-272.

https://doi.org/10.1111/hequ.12204

Hirschi, A., Zacher, H., \& Shockley, K. M. (2020). Whole-life career self-management: A conceptual framework. Journal of Career Development. https://doi.org/10.1177/0894845320957729

Horak, S. (2017). The informal dimension of human resource management in Korea. International Journal of Human Resource Management, 28(10), 1409-1432. https://doi.org/10.1080/09585192.2015.1089062

Jad’udová, J., Marková, I., Hroncová Vicianová, J., Bohers, A., \& Murin, I. (2018b). Study of consumer preferences of regional labeling. Slovak case study. European Countryside, 10, 429-441. https://doi.org/10.2478/euco-2018-0024

Jad’udová, J., Marková, I., Hroncová, E., \& Hroncová Vicianová, J. (2018a). An assessment of regional sustainability through quality labels for small farmers' products: A Slovak case study. Sustainability, 10(4), 1273. https://doi.org/10.3390/su10041273 
Joniaková, Z., \& Blštáková, J. (2015). Age management as contemporary challenge to human resources management in Slovak companies. Procedia Economics and Finance, 34, 202-209. https://doi.org/10.1016/S2212-5671(15)01620-2

Kampf, R., Hlatká, M., \& Bartuska, L. (2018). Optimization of production logistics. Advances in Science and Technology-Research Journal, 12(4), 151-156. https://doi.org/10.12913/22998624/100351

Kontodimopoulos, N., Paleologou, V., \& Niakas, D. (2009). Identifying important motivational factors for professionals in Greek hospitals. BMC Health Services Ressearch, 9(1), 164. https://doi.org/10.1186/1472-6963-9-164

Krišták, L., Němec, M., \& Danihelová, Z. (2014). Interactive methods of teaching physics at Technical Universities. Informatics in Education, 13(1), 51-71. https://doi.org/10.15388/infedu.2014.04

Kubala, J., \& Vetráková, M. (2018). Reasons of the employees' stabilization in hotels in Slovakia. Acta Oeconomica Universitatis Selye, 7(1), 90-100.

Kucharčíková, A., \& Mičiak, M. (2018). Human capital management in transport enterprises with the acceptance of sustainable development in the Slovak Republic. Sustainability, 10(7), 2530. https://doi.org/10.3390/su10072530

Kucharčíková, A., Tokarčíková, E., \& Durišová, M. (2015, September). Human capital efficiency in trading company [Conference presentation]. 9th International Days Statistics and Economics, Prague, Czech Republic.

Lejsková, P., Dvořák, L., \& Gottwald, D. (2017, September). Knowledge managemet models in creating, sharing, using and managing the knowledge and information of a company [Conference presentation]. International Scientific Conference on Knowledge for Market Use - People in Economics Decisions, Behavior and Normative Models, Olomouc, Czech Republic.

Li, J., \& Yeo, R. K. (2011). Quality of work life and career development: perceptions of part-time MBA students. Employee Relations, 33(3), 201-220. https://doi.org/10.1108/01425451111121740

Litano, M. L., \& Major, D. A. (2016). Facilitating a whole-life approach to career development: The role of organizational leadership. Journal of Career Development, 43(1), 52-65. https://doi.org/10.1177/0894845315569303

Ližbetinová, L. (2014). The quality of communication in the context of regional development. Deturope, 6(3), 22-38.

Ližbetinová, L. (2017, May). Clusters of Czech consumers with focus on domestic brands [Conference presentation]. 29th International Business Information Management Association Conference Education Excellence and Innovation Management through Vision 2020 from Regional Development Sustainability to Global Economic Growth, Vienna, Austria.

Mohyeldin, A., \& Suliman, T. (2007). Links between justice, satisfaction and performance in the workplace. Journal of Management Development, 26(4), 294-311. https://doi.org/10.1108/02621710710740075

Moresová, M., Sedliačiková, M., Štefko, J., \& Benčiková, D. (2019). Perception of wooden houses in the Slovak Republic. Acta Facultatis Xylologiae Zvolen, 61(2), 121-135. https://doi.org/10.17423/afx.2019.61.2.12

Morkevičiūtè, M., \& Endriulaitienè, A. (2020). Explaining work motivation through perceived transformational leadership. Gender in Management, 35(5), 585-599. https://doi.org/10.1108/GM-01-2020-0004

Mulyani, S. R., Sari, V. N., \& Sari, M. W. (2019). The model of employee motivation and cooperative employee performance. Polish Journal of Management Studies, 20(2), 379-390. https://doi.org/10.17512/pjms.2019.20.2.32

Muogbo, U. S. (2013). The impact of employee motivation on organisational performance. The International Journal of Engineering and Science, 2(7), 70-80.

Murphy, E. F., Gibson, J. W., \& Greenwood, R. A. (2010). Analyzing generational values among managers and non-managers for sustainable organizational effectiveness. SAM Advance Management Journal, 75(1), 33-55. 
Naile, I., \& Selesho, J. M. (2014). The role of leadership in employee motivation. Mediterranean Journal of Social Sciences, 5(3), 175-182. https://doi.org/10.5901/mjss.2014.v5n3p175

Němec, M., Krišták, L., Hockicko, P., Danihelová, Z., \& Velmovská, K. (2017). Application of innovative P\&E method at technical universities in Slovakia. Eurasia Journal of Mathematics Science and Technology Education, 13(6), 2329-2349. https://doi.org/10.12973/eurasia.2017.01228a

Nouri, B. A., \& Mousavi, M. M. (2020). The effect of career anchors on human resource development. Management Research and Practice, 12(3), 5-20.

Omondi, A. A., K’Obonyo, P., Muindi, F., Odock, S. (2019). Effect of proactive personality in the relationship between organizational sponsorship and career success of managerial staff in large manufacturing firms in Kenya. Journal of Human Resource Management, 22(1), 46-64.

Paais, M., \& Pattiruhu, J. R. (2020). Effect of motivation, leadership, and organizational culture on satisfaction and employee performance. Journal of Asian Finance Economics and Business, 7(8), 577-588. https://doi.org/10.13106/jafeb.2020.vol7.no8.577

Pacáková, V. (2009). Štatistické metódy pre ekonómov. Iura Edition, Bratislava, Slovakia.

Palm, E., Seubert, C., \& Glaser, J. (2020). Understanding employee motivation for work-to-nonwork integration behavior. Journal of Business and Psychology, 35, 683-696.

https://doi.org/10.1007/s10869-019-09648-5

Paluš, H., Parobek, J., Dzian, M., Šimo-Svrček, S., \& Krahulcová, M. (2019). How companies in the wood supply chain perceive the forest certification. Acta Facultatis Xylologiae Zvolen, 61(1), 155165. https://doi.org/10.17423/afx.2019.61.1.15

Pancheva, T. V., \& Antov, P. (2017). Application of content and language integrated learning (CLIL) in engineering education. Paper presented at the XIXth International Scientific Conference Management and Sustainable Development, Yundola, Bulgaria. Management and Sustainable Development Journal, 2(63), 36-40.

Pham, N. T., Tučková, Z., \& Phan, Q. P. T. (2019). Greening human resource management and employee commitment towards the environment: an interaction model. Journal of Business Economics and Management, 20(3), 446-465. https://doi.org/10.3846/jbem.2019.9659

Potkány, M., Debnár, M., \& Škultétyová, M. (2019). Life cycle cost analysis for reference prototype building in alternatives of silicate and wood-based structure. Acta Facultatis Xylologiae Zvolen, 61(2), 137-152. https://doi.org/10.17423/afx.2019.61.2.13

Renninger, K., \& Hidi, S. (2015). The power of interest for motivation and engagement. Routledge, London, UK. https://doi.org/10.4324/9781315771045

Salem, R., \& Yount, K. M. (2019). Structural accommodations of patriarchy: Women and workplace gender segregation in Qatar. Gender Work and Organization, 26(4), 501-519. https://doi.org/10.1111/gwao.12361

Sánchez-Sellero, M. C., Sánchez-Sellero, P., Cruz-González, M. M., \& Sánchez-Sellero, F. J. (2018). Determinants of job satisfaction in the Spanish wood and paper industries: A comparative study across Spain. Drvna Industrija, 69(1), 71-80. https://doi.org/10.5552/drind.2018.1711

Sedliačiková, M., Stroková, Z., Drábek, J., \& Malá, D. (2019). Controlling implementation: What are the benefits and barries for employees of wood processing enterprises? Acta Facultatis Xylologiae Zvolen, 61(2), 163-173. https://doi.org/10.17423/afx.2019.61.2.15

Smela, P., Pacesova, P., Kracek, S., Kukurova, K., \& Halacova, N. (2018). Achievement motivation of undergraduates divided by sport activity. Sport Mont, 16(2), 55-60. https://doi.org/10.26773/smj.180610

Son, S., \& Kim, D. Y. (2019). Organizational career growth and career commitment: Moderated mediation model of work engagement and role modeling. International Journal of Human Resource Management. https://doi.org/10.1080/09585192.2019.1657165 
Stacho, Z., Stachová, K., Papula, J., Papulová, Z., \& Kohnová, L. (2019). Effective communication in organisations increases their competitiveness. Polish Journal of Management Studies, 19(1), 391-403. https://doi.org/10.17512/pjms.2019.19.1.30

Štefancová, V., Nedeliaková, E., \& López-Escolano, C. (2017). Connection of dynamic quality modeling and total service management in railway transport operation. Procedia Engineering, 192, 834-839. https://doi.org/10.1016/j.proeng.2017.06.144

Urbancová, H., Vnoučková, L., \& Laboutková, S. (2016). Knowledge transfer in a knowledge-based economy. E \& M Ekonomie a Management, 19(2), 73-86. https://doi.org/10.15240/tul/001/2016-2-005

Weber, U., \& Rademacher, U. (2020). A road map to China the cross-cultural transfer process of a mentoring program for career development of female talent. Zeitschrift Fur Arbeits-Und Organisationspsychologie, 64(4), 278-288. https://doi.org/10.1026/0932-4089/a000339

Weng, Q. D., \& Zhu, L. (2020). Individuals' career growth within and across organizations: A review and agenda for future research. Journal of Career Development, 47(3), 239-248. https://doi.org/10.1177/0894845320921951

Xanthakis, G. (2019). Motivation process during the economic crisis: The evidence of Greek structural design engineers. Journal of Human Resource Management, 22(2), 41-51.

Xie, X., Zhu, Q., \& Qi, G. (2020). How can green training promote employee career growth? Journal of Cleaner Production, 259, 120818. https://doi.org/10.1016/j.jclepro.2020.120818

Zameer, H., Alireza, S., Nisar, W., \& Amir, M. (2014). The impact of the motivation on the employee's performance in beverage industry of Pakistan. International Journal of Academic Research in Accounting, Finance and Management Sciences, 4(1), 293-298.

https://doi.org/10.6007/IJARAFMS/v4-i1/630 